\section{JURNAL EKONOMI EFEKTIF}

ISSN : $2622-8882$, E-ISSN : 2622-9935

Jurnal Ekonomi Efektif, Vol. 2, No. 3, April 2020 @Prodi Manajemen Fakultas Ekonomi Universitas Pamulang

\title{
PENGARUH PAJAK, EXCHANGE RATE, TUNNELING INCENTIVE DAN BONUS PLAN TERHADAP TRANSAKSI TRANSFER PRICING PADA PERUSAHAAN MULTINASIONAL STUDI EMPIRIS PADA PERUSAHAAN MANUFAKTUR YANG TERDAFTAR DI BEI TAHUN 2014-2017
}

\author{
Sapta Setia Darma \\ Universitas Pamulang \\ saptasdarma@gmail.com, dosen01241@unpam.ac.id
}

\begin{abstract}
ABSTRAK
Tujuan penelitian ini untuk mengetahui pengaruh variabel pajak, exchange rate, tunnelling incentive dan bonus plan terhadap transaksi transfer pricing pada perusahaan multinasional dengan studi empiris pada perusahaan manufaktur yang terdaftar di Bursa Efek Indonesia tahun 2014-2017. Populasi penelitian adalah perusahaan manufaktur yang terdaftar di Bursa Efek Indonesia tahun 2014-2017 yang terdiri dari 157 perusahaan, sedangkan sampel penelitian adalah 44 laporan keuangan dengan empat tahun pengamatan. Pengambilan sampel menggunakan metode purposive sampling. Penelitian ini menggunakan data sekunder yaitu laporan keuangan. Hipotesis penelitian diuji menggunakan uji asumsi klasik, analisis deskriptif dan regresi linier berganda dengan menggunakan aplikasi SPSS versi 22. Hasil penelitian menunjukan bahwa secara parsial, variabel pajak berpengaruh negatif signifikan terhadap transfer pricing, variabel exchange rate berpengaruh negatif signifikan terhadap transfer pricing, variabel tunneling incentive berpengaruh negatif signifikan terhadap transfer pricing, variabel bonus plan tidak berpengaruh terhadap transfer pricing. Sedangkan secara simultan, variabel pajak, exchange rate, tunneling incentive dan bonus plan berpengaruh signifikan terhadap transfer pricing.
\end{abstract}

Kata kunci: Pajak, Exchange Rate, Tunneling Incentive, Bonus Plan, Transfer Pricing. 


\begin{abstract}
The purpose of this study was to determine the effect of variable taxes, exchange rates, tunneling incentives and bonus plans on transfer pricing transactions in multinational companies with an empirical study on manufacturing companies listed on the Indonesia Stock Exchange in 2014-2017. The study population was manufacturing companies listed on the Indonesia Stock Exchange in 2014-2017 consisting of 157 companies, while the study sample was 44 financial statements with four years of observation. Sampling using a purposive sampling method. This study uses secondary data, namely financial statements. The research hypothesis was tested using a classic assumption test, descriptive analysis and multiple linear regression using the SPSS version 22 application. The results showed that partially, the tax variable had a significant negative effect on transfer pricing, the exchange rate variable had a significant negative effect on transfer pricing, the tunneling incentive variable significant negative effect on transfer pricing, variable bonus plans do not affect transfer pricing. While simultaneously, the tax variable, exchange rate, tunneling incentive and bonus plan significantly influence transfer pricing.
\end{abstract}

Keywords: tax, exchange rate, tunneling incentive, bonus plan, transfer pricing. 


\section{PENDAHULUAN}

\section{A. Latar Belakang Masalah}

Salah satu usaha untuk mewujudkan kemandirian bangsa atau negara dalam pembangunan yaitu dengan menggali sumber dana yang berasal dari dalam negeri, yaitu pendapatan pajak (Ardyansah, 2014:1). Definisi pajak menurut Undang-Undang Nomor 16 tahun 2009 yang merupakan perubahan keempat atas Undang-Undang Nomor 6 tahun 1983 tentang Ketentuan Umum dan Tata Cara Perpajakan pada Pasal 1 ayat 1 menyebutkan bahwa pajak adalah kontribusi wajib kepada Negara yang terutang oleh orang pribadi atau badan yang bersifat memaksa berdasarkan undang-undang, dengan tidak mendapatkan imbalan secara langsung dan digunakan untuk keperluan Negara bagi sebesar-besarnya kemakmuran rakyat. Menurut Soemitro dalam Mardiasmo (2016:1) pajak adalah iuran rakyat kepada kas Negara berdasarkan undang-undang (yang dapat dipaksakan) dengan tiada mendapat jasa timbal (kontraprestasi) yang langsung dapat ditunjukkan dan yang digunakan untuk membayar pengeluaran umum.

Karena sifatnya yang wajib, maka banyak wajib pajak yang berusaha menghindari pajak melalui bermacam-macam skema, mulai dari hybrid financial instrument (instrument keuangan campuran) dengan cara mengesploitasi perbedaan perlakuan pajak antara hutang dan modal saham dengan membuat pembiayaan hutang yang padahal sebenarnya subtansinya adalah modal saham atau sebaliknya, hingga penyalahgunaan P3B (Perjanjian Penghindaran Pajak Berganda). Dari sekian banyak skema, manipulasi transfer pricing adalah suatu strategi penghindaran pajak yang paling dominan atau sering dipergunakan (Josh and Michael, 2013 dalam Darussalam dan Septriadi, 2017:654).

Menurut Setiawan (2014:2), transfer pricing (penentuan harga transfer) adalah kebijakan perusahaan dalam menentukan harga transfer suatu transaksi baik itu barang, jasa, harta tak berwujud, ataupun transaksi finansial yang dilakukan oleh perusahaan antara pihak-pihak yang mempunyai hubungan istimewa. Walaupun istilah transfer pricing tersebut sebenarnya merupakan istilah yang netral, tetapi dalam praktiknya istilah transfer pricing sering kali diartikan sebagai upaya untuk memperkecil pajak dengan cara menggeser harga atau laba antarperusahaan dalam satu grup.

Perkembangan transfer pricing tidak lepas dari globalisasi. Globalisasi berperan mengurangi atau bahkan menghilangkan hambatan antarnegara dalam rangka memudahkan arus barang, jasa, modal, dan sumber daya manusia antarnegara. Globalisasi telah memunculkan tumbuh dan berkembangnya perusahaan multinasional. Kemajuan yang pesat dalam teknologi, transportasi, dan komunikasi memberikan kemudahan bagi perusahaan multinasional dalam menempatkan usaha mereka di negara manapun di belahan dunia. Kenyataannya sebagian besar transaksi perdagangan internasional saat ini melibatkan perusahaan multinasional dalam satu grup (intra-group transactions) (Kurniawan, 2015:1).

Dalam konsep perdagangan internasional, setiap negara yang tergabung di dalamnya harus menyamakan dulu sistem moneternya yaitu alat pembayarannya, dalam melakukan transaksi perdagangan digunakanlah kurs valuta asing (Exchange Rate). Nilai tukar atau kurs menunjukkan seberapa besar rupiah yang dibutuhkan untuk memperoleh uang asing. Sedangkan arus kas perusahaan multinasional didenominasikan atau memerlukan penyelesaian dalam suatu mata uang asing dimana nilai setiap mata uang relatif kepada nilai dolar akan berbeda seiring dengan perbedaan waktu. Exchange rate yang berbeda-beda inilah yang nantinya akan mempengaruhi praktik transfer pricing pada perusahaan multinasional (Marfuah dan Azizah, 2014). 


\section{B. Perumusan Permasalahan Penelitian}

1. Apakah pajak berpengaruh terhadap keputusan perusahaan dalam melakukan transfer pricing?

2. Apakah exchange rate berpengaruh terhadap keputusan perusahaan dalam melakukan transfer pricing?

3. Apakah tunneling incentive berpengaruh terhadap keputusan perusahaan dalam melakukan transfer pricing?

4. Apakah bonus plan berpengaruh terhadap keputusan perusahaan dalam melakukan transfer pricing?

5. Apakah pajak, exchange rate, tunneling incentive, dan bonus plan berpengaruh terhadap keputusan perusahaan dalam melakukan transfer pricing?

\section{Manfaat Penelitian}

1. Regulator, dalam hal ini adalah Direktorat Jendral Pajak (DJP) dan Badan Pengawasan Pasar Modal dan Lembaga Keuangan (Bapepam-LK). Penelitian ini diharapkan dapat memberikan bukti empiris yang berhubungan dengan pentingnya pengawasan serta efektifitas peraturan yang telah dikeluarkan mengenai pajak, exchange rate, tunneling incentive dan bonus plan terhadap keputusan transfer pricing sehingga dapat meminimalisir kecurangan maupun penyelewengan terhadap kebijakan harga transfer di Indonesia.

2. Manajemen, penelitian ini diharapkan dapat memberikan masukan mengenai pajak, exchange rate, tunneling incentive dan bonus plan terhadap keputusan harga transfer perusahaan multinasional di Indonesia. Sehingga dapat membantu suatu pengambilan keputusan dan menambah kesadaran akan pentingnya etika bisnis.

\section{METODE PENELITIAN}

Penelitian dilakukan pada perusahaan manufaktur di Bursa Efek Indonesia (BEI) pada periode 4 tahun mulai tahun 2014-2017 yang beralamatkan di Gedung Bursa Efek Indonesia, Menara I Jl. Jendral Sudirman Kav 52-53 Jakarta Selatan 12190, Indonesia. No. Tlp: 021 - 5150515, Fax: 021 - 5150330, dimana pada proses pengambilan data, peneliti mengunjungi website resmi Bursa Efek Indonesia Bursa Efek Indonesia (BEI) yaitu (www.idx.co.id) untuk memperoleh data laporan keuangan perusahaan. Dipilihnya BEI sebagai tempat penelitian karena BEI merupakan bursa pertama di Indonesia yang dianggap memiliki data yang lengkap dan telah terorganisasi dengan baik. Menurut Sugiyono (2012:38) variabel penelitian pada dasarnya adalah suatu atribut atau sifat atau nilai dari orang, obyek atau kegiatan yang mempunyai variasi tertentu yang ditetapkan oleh peneliti untuk dipelajari dan ditarik kesimpulannya. Sedangkan menurut Machali (2016:48) menyatakan variabel penelitian adalah apa yang menjadi fokus dalam sebuah penelitian. Menurut peneliti variabel penelitian adalah objek penelitian yang menjadi fokus didalam penelitian yang sedang diteliti dan dipelajari serta ditarik kesimpulannya.

\section{HASIL PENELITIAN DAN PEMBAHASAN}

\section{A. Pengaruh pajak Terhadap Transaksi Transfer Pricing}

Secara parsial variabel pajak berpengaruh negatif signifikan terhadap transfer pricing. Hal tersebut dibuktikan dengan hasil pajak memiliki t-hitung lebih kecil daripada $\mathrm{t}$-tabel $(-2,759<2,02269)$ dengan tingkat signifikasi sebesar 0,009 $<0,05$ sehingga H0 ditolak dan $\mathrm{H} 1$ diterima, maka dapat disimpulkan bahwa variabel pajak berpengaruh negatif signifikan terhadap transfer pricing. 
Hal ini berarti bahwa semakin meningkatnya pajak yang dikenakan maka perusahaan dalam melakukan transfer pricing dengan pihak yang mempunyai hubungan istimewa akan menurun atau sebaliknya. Hasil penelitian ini konsisten dengan penelitian yang dilakukan oleh Marfuah dan Azizah (2014) yang menunjukkan bahwa pajak berpengaruh negatif signifikan terhadap transfer pricing. Hasil ini tidak sesuai dengan penelitian yang dilakukan oleh Saifudin dan Putri (2018) dan Mispiyanti (2015) yang menyimpulkan pajak tidak berpengaruh terhadap keputusan transfer pricing perusahaan.

\section{B. Pengaruh Exchange Rate Terhadap Transaksi Transfer Pricing}

Secara parsial variabel exchange rate berpengaruh negatif signifikan terhadap transfer pricing. Hal tersebut dibuktikan dengan hasil pajak memiliki t-hitung lebih kecil daripada t-tabel $(-2.602<2,02269)$ dengan tingkat signifikasi sebesar $0,013<0,05$ sehingga $\mathrm{H}_{2}$ diterima dan $\mathrm{H} 0$ ditolak. Hal ini menunjukkan bahwa hipotesis kedua yang menyatakan bahwa exchange rate berpengaruh terhadap transaksi transfer pricing, didukung.

Artinya besar-kecilnya exchange rate mempengaruhi pertimbangan perusahaan apakah perusahaan akan memilih untuk melakukan transaksi transfer pricing atau memilih untuk tidak melakukan transaksi transfer pricing. Hasil ini dapat berarti bahwa perusahaan multinasional tidak mencoba untuk mengurangi risiko nilai tukar (exchange rate) mata uang asing dengan memindahkan dana ke mata uang yang kuat melalui transfer pricing untuk memaksimalkan keuntungan perusahaan secara keseluruhan. Hal ini tidak sesuai dengan penelitian yang dilakukan oleh Marfuah dan Azizah (2014) yang menunjukkan bahwa exchange rate berpengaruh positif tapi tidak signifikan terhadap transfer pricing.

\section{Pengaruh Tunneling Incentive Terhadap Transaksi Transfer Pricing}

Secara parsial variabel tunneling incentive berpengaruh negatif signifikan terhadap transaksi transfer pricing. Hal tersebut dibuktikan dengan hasil tunneling incentive memiliki t-hitung lebih kecil daripada t-tabel $(-2.539<2,02269)$ dengan tingkat signifikasi sebesar $0,015<0,05$ sehingga $\mathrm{H}_{3}$ diterima dan $\mathrm{H} 0$ ditolak, maka secara parsial terbukti bahwa tunneling incentive berpengaruh negatif signifikan terhadap transfer pricing.

Hal ini berarti bahwa semakin besar saham yang dimiliki oleh pemegang saham maka semakin kecil kemungkinan untuk melakukan transfer pricing. Hasil penelitian ini konsisten dengan penelitian yang dilakukan oleh Hartati dkk (2014), Noviastika dkk (2016), Refgia (2017) dan Mispiyanti (2015) yang menunjukkan bahwa tunneling incentive berpengaruh secara signifikan terhadap transfer pricing. Hasil ini tidak sesuai dengan penelitian yang dilakukan oleh Saifudin dan Putri (2018) yang menyimpulkan bahwa tunneling incentive tidak berpengaruh terhadap keputusan transfer pricing.

\section{Pengaruh Bonus Plan Terhadap Transaksi Transfer Pricing}

Secara parsial variabel bonus plan tidak berpengaruh terhadap transfer pricing. Hal tersebut dibuktikan dengan hasil bonus plan memiliki t-hitung lebih kecil daripada t-tabel $(1,780<2,02269)$ dengan tingkat signifikasi sebesar 0,83>0,05 sehingga $\mathrm{H} 0$ diterima dan $\mathrm{H}_{4}$ ditolak, Hal ini menunjukkan bahwa hipotesis keempat yang menyatakan bahwa bonus plan berpengaruh terhadap transaksi transfer pricing, tidak didukung. Artinya berdasarkan hasil nilai indeks trend laba bersih pada penelitian yang dilakukan, indeks 
trend laba bersih cenderung stabil. Dengan nilai yang stabil ini menunjukan perusahaan kurang tertarik dalam memanipulasi laba dengan melakukan transfer pricing untuk mendapatkan bonus.

Hasil penelitian ini tidak sesuai dengan teori agensi yang menyatakan bahwa para direksi mungkin mencoba untuk mendapatkan bonus dengan mekanisme transfer pricing untuk memaksimalkan keuntungan perusahaan secara keseluruhan. Hasil penelitian ini konsisten dengan penelitian yang dilakukan oleh Saraswati dan Sujana (2017), Refgia (2017) dan Mispiyanti (2015) yang menunjukkan bahwa bonus plan tidak berpengaruh secara signifikan terhadap keputusan transfer pricing. Hasil ini tidak sesuai dengan penelitian yang dilakukan oleh Hartati dkk (2014) serta Saifudin dan Putri (2018) yang menyimpulkan bahwa bonus plan berpengaruh terhadap keputusan perusahaan dalam melakukan transfer pricing

\section{E. Pengaruh Pajak, Exchange Rate, Tunneling Incentive, dan Bonus Plan Terhadap Transaksi Transfer Pricing}

Hasil uji statistik F pada tabel 4.10 dapat diketahui bahwa nilai $\mathrm{F}$ hitung sebesar 3,439 dengan $F$ tabel sebesar 2,61 dan nilai signifikansi sebesar 0,017. Karena $F$ hitung $>$ F tabel dengan nilai Sig. 0,017 < 0,05 maka hipotesis kelima (H5) diterima. Sehingga dapat disimpulkan bahwa variabel independen yaitu pajak, exchange rate, tunneling incentive dan bonus plan secara bersama-sama (simultan) berpengaruh terhadap variabel dependen yaitu transaksi transfer pricing. Hasil ini sesuai dengan penelitian yang dilakukan oleh Wafiroh dan Hapsari (2015) serta Jasmine dkk (2018) dimana variabel independen yang diteliti adalah pajak, tunneling incentive dan mekanisme bonus dengan variabel dependennya transfer pricing, menunjukkan bahwa secara simultan, variabel pajak, tunneling incentive dan mekanisme bonus berpengaruh terhadap keputusan perusahaan dalam melakukan transfer pricing

\section{PENUTUP}

\section{A. Kesimpulan}

1. Secara parsial, variabel pajak berpengaruh negatif signifikan terhadap transfer pricing pada perusahaan manufaktur yang terdaftar di Bursa Efek Indonesia periode 2014-2017. Hal ini ditunjukkan dari statistik untuk variabel pajak diketahui bahwa koefisien regresi pajak bernilai $-1,172$, hasil uji statistik t untuk variabel insentif pajak diperoleh nilai signifikansi 0,009, sehingga lebih kecil dari nilai tingkat signifikan sebesar 0,05 . Hasil ini menunjukkan bahwa semakin tinggi tarif pajak yang dikenakan maka akan menurunkan keputusan perusahaan dalam melakukan transfer pricing atau sebaliknya. Dalam penelitian ini, kemungkinan perusahaan mengurangi beban pajak perusahaan yang tinggi dengan menerapkan manajemen pajak, bukan melalui transfer pricing. Hal ini sejalan dengan penelitian yang dilakukan oleh Marfuah dan Azizah (2014) yang menunjukkan bahwa pajak berpengaruh negatif signifikan terhadap transfer pricing. Hasil ini tidak sesuai dengan penelitian yang dilakukan oleh Saifudin dan Putri (2018) serta Mispiyanti (2015) yang menyimpulkan pajak tidak berpengaruh terhadap keputusan perusahaan dalam melakukan transfer pricing.

2. Secara parsial, variabel exchange rate berpengaruh negatif signifikan terhadap transfer pricing pada perusahaan manufaktur yang terdaftar di Bursa Efek Indonesia periode 2014-2017. Hal ini ditunjukkan dari statistik untuk variabel exchange rate diketahui bahwa koefisien regresi exchange rate bernilai $-1,725$, hasil uji statistik t untuk variabel exchange rate diperoleh nilai signifikansi sebesar 
0,013, sehingga lebih besar dari nilai tingkat signifikan sebesar 0,05 . Artinya besarkecilnya exchange rate mempengaruhi pertimbangan perusahaan apakah perusahaan akan memilih untuk melakukan transaksi transfer pricing atau memilih untuk tidak melakukan transaksi transfer pricing. Perusahaan multinasional mungkin tidak mencoba untuk mengurangi risiko nilai tukar (exchange rate) mata uang asing dengan memindahkan dana ke mata uang yang kuat melalui transfer pricing untuk memaksimalkan keuntungan perusahaan secara keseluruhan, namun dengan cara lain. Hasil penelitian ini bertolak belakang dengan penelitian yang dilakukan oleh Marfuah dan Azizah (2014) yang menunjukkan bahwa pajak berpengaruh secara positif tapi tidak signifikan terhadap transfer pricing.

3. Secara parsial, variabel tunneling incentive berpengaruh negatif signifikan terhadap transfer pricing pada perusahaan manufaktur yang terdaftar di Bursa Efek Indonesia periode 2014-2017. Hal ini ditunjukkan dari statistik untuk variabel tunneling incentive diketahui bahwa koefisien regresi tunneling incentive sebesar 0,625 , hasil uji statistik $t$ untuk variabel insentif pajak diperoleh nilai signifikansi 0,015 , sehingga lebih kecil dari nilai tingkat signifikan sebesar 0,05 . Semakin besar saham yang dimiliki oleh pemegang saham maka semakin kecil kemungkinan untuk melakukan transfer pricing, begitu pula sebaliknya. Hasil penelitian ini konsisten dengan penelitian yang dilakukan oleh Hartati dkk (2014), Noviastika dkk (2016), Refgia (2017) dan Mispiyanti (2015) yang menunjukkan bahwa tunneling incentive berpengaruh secara signifikan terhadap transfer pricing. Hasil ini tidak sesuai dengan penelitian yang dilakukan oleh Saifudin dan Putri (2018) yang menyimpulkan bahwa tunneling incentive tidak berpengaruh terhadap keputusan transfer pricing.

4. Secara parsial, variabel bonus plan tidak berpengaruh terhadap transfer pricing pada perusahaan manufaktur yang terdaftar di Bursa Efek Indonesia periode 20142017. Hal ini ditunjukkan dari statistik untuk variabel bonus plan diketahui bahwa koefisien regresi bonus plan bernilai 0,167 , hasil uji statistik t untuk variabel insentif pajak diperoleh nilai signifikansi sebesar 0,83 , sehingga lebih besar dari nilai tingkat signifikan sebesar 0,05. Hasil penelitian ini tidak sesuai dengan teori agensi yang menyatakan bahwa para direksi mungkin mencoba untuk mendapatkan bonus dengan mekanisme transfer pricing untuk memaksimalkan keuntungan perusahaan secara keseluruhan. Hasil penelitian ini konsisten dengan penelitian yang dilakukan oleh Saraswati dan Sujana (2017), Refgia (2017) dan Mispiyanti (2015) yang menunjukkan bahwa bonus plan tidak berpengaruh secara signifikan terhadap keputusan transfer pricing. Hasil ini tidak sesuai dengan penelitian yang dilakukan oleh Hartati dkk (2014) serta Saifudin dan Putri (2018) yang menyimpulkan bahwa bonus plan berpengaruh terhadap keputusan perusahaan dalam melakukan transfer pricing.

5. Secara simultan, variabel pajak, exchange rate, tunneling incentive dan bonus plan berpengaruh terhadap transaksi transfer pricing pada perusahaan manufaktur yang terdaftar di Bursa Efek Indonesia periode 2014-2017. Hal ini ditunjukkan dari statistik diketahui bahwa nilai $\mathrm{F}$ hitung sebesar 3,439 dengan $\mathrm{F}$ tabel sebesar 2,61 dan nilai signifikansi sebesar 0,017. Karena F hitung > Ftabel dengan nilai Sig. $0,017<0,05$ maka dapat disimpulkan variabel pajak, exchange rate, tunneling incentive dan bonus plan secara bersama-sama berpengaruh terhadap transaksi transfer pricing 


\section{B. Saran}

Berdasarkan hasil analisis, pembahasan, dan kesimpulan, adapun implikasi dari penelitian yang telah dilakukan, yakni dinyatakan dalam bentuk saran-saran yang diberikan melalui hasil penelitian yaitu, Bagi Perusahaan. Perusahaan hendaknya meningkatkan kinerja perusahaan tiap tahunnya agar mampu bersaing dalam memperoleh kepercayaan dari investor sehingga memudahkan untuk memperoleh modal dari luar perusahaan. Bagi Investor. Investor yang akan melakukan investasi di pasar modal, hasil penelitian ini diharapkan dapat berguna sebagai bahan pertimbangan dalam pengambilan keputusan investasi.

Bagi Akuntan Publik. Penelitian ini dapat digunakan sebagai salah satu pertimbangan agar pengungkapan yang cukup dan penjelasan yang memadai tentang variabel pajak, exchange rate, tunneling incentive, bonus plan dan transfer pricing yang dilaporkan dalam pelaporan keuangan, sesuai dengan PSAK tentang Akuntansi Pajak Penghasilan. Bagi Penelitian selanjutnya. Penelitian lebih lanjut diharapkan dapat menambah faktor lain yang mungkin berpengaruh terhadap keputusan perusahaan melakukan transfer pricing. Seperti debt covenant bahwa sesuai dengan debt hypothesis dimana perusahaan yang memiliki rasio utang tinggi cenderung menggunakan metode akuntansi yang dapat menaikkan laba perusahaannya. Peneliti selanjutnya dapat menambah jumlah sampel yang diteliti dan populasi penelitian tidak hanya dikhususkan pada perusahaan manufaktur, tetapi dapat diperluas pada kelompok perusahaan lainnya yang terdaftar di Bursa Efek Indonesia.

\section{DAFTAR PUSTAKA}

Agoes, Sukrisno. 2014. Akuntansi Perpajakan. Edisi 3. Salemba Empat: Jakarta.

Anthony, Robert N. dan Govindarajan, Vijay. 2005. Sistem Pengendalian Manajemen Cetakan pertama. Edisi 11. Salemba Empat: Jakarta.

Ardyansah, Danis. 2014. Pengaruh Size, Leverage, Profitability, Capital Intensity Ratio dan Komisaris Independen Terhadap Efective Tax Rate (ETR). Skripsi. Fakultas Ekonomi dan Bisnis Universitas Diponegoro: Semarang.

Bhakti dan Primanto, Astera. 2002. Transfer Pricing Suatu Kajian Perpajakan. Jurnal Perpajakan Indonesia.

Brundy, Edwin Pratama. 2014. Pengaruh Mekanisme Pengawasan Terhadap Aktivitas Tunneling. Skripsi. Universitas Atma Jaya.

Ekananda, Mahyus. 2014. Ekonomi Internasional. Erlangga: Jakarta.

Darmawan. 2016. Metode Penelitian Kuantitatif, Remaja Rosdakarya: Bandung.

Darussalam dan Septriadi, Danny. 2017. Perjanjian Penghindaran Pajak Berganda. DDTC (PT Dimensi International Tax): Jakarta.

Fitrah, M. dan Luthfiyah. 2017. Metode Penelitian: Penelitian Kualitatif, Tindakan Kelas \& Studi Kasus, CV Jejak: Sukabumi.

Ghozali, Imam. 2013. Aplikasi Analisis Multivariate dengan Program IBM SPSS 21. Edisi ke 7. Badan Penerbit Universitas Diponegoro: Semarang.

Gumilar, I., Sunarsi, D. (2020). Comparison of financial performance in banking with high car and low car (Study of banks approved in the kompas 100 index for the period 2013-2017). International Journal of Psychosocial Rehabilitation. Volume 24 Issue 7

Goeltom, Miranda S. dan Zulverdi, Doddy. 1998. Manajemen Nilai Tukar di Indonesia dan Permasalahannya..

Hartati, Winda., Desmiyawati, dan Julita. 2014. Tax Minimization, Tunneling Incentive dan Mekanisme Bonus Terhadap Keputusan Transfer Pricing Seluruh Perusahaan 
yang Listing di Bursa Efek Indonesia. Jurnal Simposium Nasional. Universitas Riau.

Hidayat, A., \& Sunarsi, D. (2020). Faktor-Faktor Yang Mempengaruhi Dana Pihak Ketiga Dan Dampaknya Terhadap Profitabilitas (Survey Pada Bpr Syariah Di Jawa Barat Tahun 2014-2017). Jurnal Proaksi, 7(1), 54-65.

Ikatan Akuntansi Indonesia. PSAK No. 15, Jakarta, 2015.

J. Supranto. 2013. Statistik Teori dan Aplikasi. Edisi Lima. Erlangga: Jakarta.

Jensen, M.C dan Meckling. 1976. Theory of The Firm: Manajerial Behavior, Agency Cost and Ownership Structure. Journal of Financial Economics 3. 305-360.

Kewal, Suramaya Suci. 2012. Pengaruh Inflasi, Suku Bunga, Kurs, dan Pertumbuhan PDB Terhadap Indeks Harga Saham. Jurnal Economi. Volume 8. Nomor 1 April.

Kieso, D. E., Weygandt, J. J., \& Warfield, T. D. 2011. Intermediate Accounting Volume 1 IFRS Edition. Wiley: United States of America.

Kurniawan, Anang Mury. 2015. Transfer Pricing untuk Kepentingan Pajak. Andi Offset: Yogyakarta.

Lupiyoadi, Rambat dan Ikhsan, Ridho Bramulya. 2015. Praktikum Metode Riset Bisnis, Salemba Empat: Jakarta.

Machali, Rochayah. 2016. Metode Penelitian Bisnis. Salemba Empat: Jakarta.

Mardiasmo. 2016. Perpajakan Edisi Terbaru. Andi: Yogyakarta.

Marfuah dan Azizah, A. P. N. 2014. Pengaruh Pajak, Tunneling Incentive dan Exchange Rate pada Keputusan Transfer Pricing Perusahaan. JAAI. 18(2): 156-165. Diakses 13 Agustus 2017 dari www.journal.uii.ac.id.

Mispiyanti. 2015. Pengaruh Pajak, Tunneling Incentive dan Mekanisme Bonus Terhadap Keputusan Transfer Pricing. Jurnal Akuntansi dan Investasi. 16(1): 62-73. Diakses 18 Juli 2017 dari www.journal.umy.ac.id.

News.ddtc.co.id

Nofiana, L., \& Sunarsi, D. (2020). The Influence of Inventory Round Ratio and Activities Round Ratio of Profitability (ROI). JASa (Jurnal Akuntansi, Audit dan Sistem Informasi Akuntansi), 4(1), 95-103.

Noviastika, dkk. 2016. Pengaruh Pajak, Tunneling Incentive dan Good Corporate Governance (GCG) Terhadap Indikasi Melakukan Transfer Pricing Pada Perusahaan Manufaktur Yang Terdaftar Di Bursa Efek Indonesia (Studi Pada Bursa Efek Indonesia yang Berkaitan dengan Perusahaan Asing). Jurnal Perpajakan (JEJAK) Vol. 8 No. 1 2016. dari perpajakan.studentjournal.ub.ac.id

Pramana, 2014. Pengaruh Pajak, Bonus Plan, Tunneling Incentive, dan Debt Covenant Terhadap Keputusan Perusahaan Untuk Melakukan Transfer Pricing (Studi Empiris pada Perusahaan Manufaktur yang Terdaftar di Bursa Efek Indonesia Tahun 2011-2013). Skripsi. Universitas Diponegoro.

Refgia, Thessa. 2017. Pengaruh Pajak, Mekanisme Bonus, Ukuran Perusahaan, Kepemilikan Asing, Tunneling Incentive Terhadap Transfer Pricing. JOM Fekon Vol. 4 No. 1 Februari 2017: 543- 555. Diakses 12 Agustus 2017 dari www.jom.unri.ac.id

Resmi, Siti. 2009. Perpajakan Teori dan Kasus. Salemba Empat: Jakarta.

Saifudin,. Putri, Luky Septiani. 2017. Determinasi Pajak, Mekanisme Bonus, dan Tunneling Incentive Terhadap Keputusan Transfer Pricing Pada Emiten BEI. Jurnal Ekonomi dan Bisnis Vol. 2, No. 1, Maret 2018.http://journal.uhamka.ac.id/index.php/agregat 
Santoso, Imam. 2004. Advance Pricing Agreement dan Problematika Transfer Pricing dari Perspektif Perpakajan Indonesia. Skripsi. Jurusan Ekonomi Akuntansi Fakultas Ekonomi. Universitas Kristen Petra. http://puslit.petra.ac.id/ puslit/journals/

Saraswati dan Sujana. 2017. Pengaruh Pajak, Mekanisme Bonus, Dan Tunneling Incentive Pada Indikasi Melakukan Transfer Pricing. E-Jurnal Akuntansi Universitas Udayana Vol.19.2. Mei 2017: 1000-1029. Diakses 18 Agustus 2017 dari www.ojs.unud.ac.id

Sari, Ratna Candra. dan Sugiharto. 2014. Tunneling dan Corporate Governance. Gadjah Mada University Press: Yogyakarta.

Sekaran, Uma. 2011. Research Methods for Business (Metodologi Penelitian untuk Bisnis). Salemba Empat: Jakarta.

Septarini, Nisa. 2012. Regulasi dan Praktik Transfer Pricing di Indonesia dan Negara Maju. Skripsi Universitas Negeri Surabaya.

Setiawan, Hadi. 2014. Transfer Pricing dan Risikonya Terhadap Penerimaan Negara. dari www.kemenkeu.go.id

Sudaryono, dkk. 2014. Pengembangan Instrumen Penelitian Pendidikan. Graha Ilmu: Yogyakarta.

Sugiyono. 2014. Metode Penelitian Bisnis. Alfabeta: Bandung.

Sunyoto, Danang. 2016. Metode dan Instrumen Peneltian Ekonomi dan Bisnis. Caps Publishing: Jakarta.

Suprianto, Dicky dan Raisa Pratiwi. 2018. Pengaruh beban pajak, kepemilikan asing, dan ukuran perusahaan terhadap transfer pricing. Skripsi. Jurusan Akuntansi STIE Multi Data Palembang.

Sutedi, Adrian. 2015. Buku Pintar Hukum Perseroan Terbatas. Raih Asa Sukses: Jakarta.

Swarjana, I Ketut. 2015. Metodologi Penelitian Kesehatan [Edisi Revisi]. Andi: Yogyakarta.

Syarifuddin, Ferry. 2016. Konsep, Dinamika dan Respon Kebijakan Nilai Tukar Di Indonesia.BI Institute: Jakarta.

Wafiroh dan Hapsari. 2015. Pengaruh Pajak, Tunneling Incentive dan Mekanisme Bonus Pada Keputusan Transfer Pricing. Skripsi S1. Universitas Negeri Islam Maulana Malik Ibrahim: Malang.

Waluyo, Wirawan. 2013. Perpajakan Indonesia. Salemba Empat: Jakarta.

Yuniasih, dkk. 2012. Pengaruh Pajak Dan Tunneling Incentive Pada Keputusan Transfer Pricing Perusahaan Manufaktur Yang Listing Di Bursa Efek Indonesia. Jurnal Universitas Udayana. 